\title{
Espressocultuur in plaats van rechtvaardige steden
}

AUTEUR \& FOTOGRAFIE Yvonne Rijpers

\section{Naar aanleiding van haar boek 'Naked City' en haar verblijf in Amsterdam, sprak AGORA met Sharon Zukin. Over haar boek, haar visie en haar doelgroep. Een interview, interessant vanwege haar inhoude- lijke werk, maar ook om wat Zukin impliciet en expliciet te melden heeft over hypes en haar eigen rol daarin.}

Sharon Zukin is professor Sociologie aan Brooklyn College en het Graduate Centre van de City University of New York. Onderwerpen waar ze zich mee bezighoudt zijn cultuur en vastgoed in New York, culturele productie en consumptie, het veranderen van de stad door de-industrialisatie, gentrificatie en immigratie. Ze is bekend van haar boeken 'Loft Living' en 'The Cultures of Cities'. 'Naked City, the death and life of authentic urban places', is haar laatst verschenen boek. De achterflap van het boek belooft een "essentieel kompas voor mensen die worstelen met de kracht van het hedendaagse kapitalisme in hun dagelijkse omgeving". Een kompas is het echter niet, alleen al omdat het kernbegrip van het boek - authenticiteit veel te diffuus is om houvast aan te bieden.

Voor hedendaagse, gegentrificeerde stedelingen, staat authenticiteit gelijk aan zaken zoals oude gebouwen, galerieën, boetiekjes,

traiteurs, biologische markten, koffietentjes en etnische restaurantjes. Zukin beschrijft het als een totaalsfeer, een beleving van een plek die samenhangt met wat die plek te bieden heeft; zoals de bebouwde omgeving, het soort gebruikers, het gevoel van veiligheid, het soort winkels en ander vrijetijdsaanbod. Volgens haar neemt de vraag naar authenticiteit wereldwijd toe, wat zich uit in een opschaling van wijken (gentrificering) en escalerende vastgoedprijzen. Tegelijkertijd zorgt dit ervoor dat de mensen die deze wijken hun aantrekkelijke authenticiteit geven, weggejaagd worden omdat het te duur voor ze wordt om te blijven. Aan de hand van verschillende voorbeelden op verschillende plekken in New York doet Zukin uit de doeken hoe dit proces werkt, of eigenlijk niet werkt, aangezien de begeerde authenticiteit verjaagd wordt samen met de mensen die de wijk authentiek maken.

\section{Vocabulaire van de straat}

Authenticiteit is een moeilijk in te kaderen wetenschappelijk concept. Zukin noemt het zelf elitair, chaotisch, normatief en empirisch. Kortom, een gek concept. Mensen om haar heen verklaarden haar voor gek dat ze over een dergelijk concept wilde schrijven en publiceren. Echter, het is een concept dat tot het hedendaagse vocabulaire behoort en volgens haar daarom juist geschikt om te gebruiken. Ze vertelt dat de term zo alomtegenwoordig is, dat de woorden authenticiteit en espresso cafés, ook bij haar Afro-Amerikaanse studenten uit wijken met lage huren een belletje doet rinkelen. Ook in hun voorheen homogene wijken zien zij blanke mensen joggen en andere voorzieningen verschijnen. Ze zien hun wijken verkleuren, verhippen en duurder worden; de plaatselijke kleine supermarkten verdwijnen, koffiebars en delicatessenzaken verschijnen. Dit is het effect van de vraag naar authenticiteit en dit zijn de voorbeelden die volgens Zukin iedere stedeling onmiddellijk begrijpt. "Ik probeer me te richten op de mensen die het woord authenticiteit al gebruiken. Tegen hen zeg ik: laten we het hebben over wijken en steden, met dit vocabulaire. En als je op deze manier kijkt, wat is dan een authentieke wijk? En als je op zoek bent naar authenticiteit, is het dan niet zo dat je de kans loopt om authenticiteit de das om te doen, omdat je naar een wijk verhuist terwijl de authentieke mensen daar wegtrekken? Ik probeer dit soort spanning aan he $\mathrm{t}$ licht te brengen in het boek."

\section{Engagement}

Naked city is een geëngageerd boek dat burgers bewust wil maken en als het even kan veranderingen teweeg wil brengen. Zelf zegt Zukin wetten van steden zoals New York te willen aanpassen zodat 
mensen, zowel bewoners als winkeliers, niet weggejaagd worden uit hun buurt, maar de kans krijgen om te blijven waar ze willen blijven. Met het boek richt ze zich tot beleidsmakers en mensen uit de 'hogere middenklasse' waartoe ze ook zichzelf rekent; vaak dezelfde personen die gentrifiers zijn. Het proces van gentrificatie en herontwikkeling dat de laatste twintig tot dertig jaar in New York plaatsvindt, het 'opschalen van buurten' zoals ze dat noemt, kenschetst ze als een continue verandering naar een postindustriële economie. Een economie die geen plek heeft voor mensen met die vooral met hun handen werken. Stedelijke centra worden weer eigendom van de rijkere mensen, de hogere middenklasse. Zukin wil bij haar lezers de bewustwording creëren wat het effect is van authenticiteit. Ze wil dat ze beseffen dat de smaak van gentrifiers (de hogere middenklasse en hopelijk ook haar leespubliek), in culturele goederen en stedelijke omgevingen het effect heeft dat bepaalde mensen weggejaagd worden. "Mijn boek levert een bijdrage aan het bestuderen van steden door te zeggen: ja, we moeten kijken naar kapitaal en nationaal beleid, maar we moeten ook kijken naar consumentencultuur en de media - die niet zelf dingen creëren, maar wel drijvers zijn van veel van deze veranderingen."

\section{Wetenschappelijke concepten zijn voor Zukin niet sexy genoeg om haar boodschap over te brengen}

\section{Een hype-boek?}

Door aan te sluiten bij het vocabulaire van de straat, maakt Zukin een duidelijke keuze; een keuze tegen het wetenschappelijke discours en voor het bereik van een groter, niet-wetenschappelijk publiek. Een gedurfde keus, waarmee Zukin zich in zekere zin schaart bij de Richard Florida's van de wetenschappelijke wereld. Zelf noemt ze het liever een artistieke beslissing, omdat ze mensen probeert te bereiken vanuit hun eigen referentiekader om ze van daaruit mee te nemen, in plaats van ze proberen te dwingen haar gedachtelijn te volgen. Zukin maakt echter niet alleen de keuze voor een bepaald discours, ze maakt ook de keuze voor een bepaalde opbouw en uitwerking van haar boek, gericht op een bepaald publiek en met een doel - de stedeling aanzetten tot verandering - dat afwijkt van het wetenschappelijk niveau dat je van haar zou verwachten. Inderdaad, Naked City is toegankelijk, begrijpelijk en met taal en voorbeelden die de hedendaagse stedeling moeiteloos begrijpt. Dit heeft als gevolg dat het boek leunt op een dun wetenschappelijk kader, erg veel beschrijvingen en heeft amper eenduidige conclusies. In plaats van dat Zukin iets onderzoekt, een patroon ontdekt, een mogelijke oplossingsrichting aandraagt of conclusie trekt, blijkt dat ze het zelf eigenlijk ook niet zo goed weet. Dit geeft ze ook meermalen aan in het gesprek; de vraag omtrent authenticiteit en de rechtvaardige stad blijft een dagelijkse worsteling tussen wat belangrijk is voor een individu (in deze de gentrifiers) en wat in breder maatschappelijk oogpunt wenselijk is. En ook over dat laatste is uiteraard geen consensus.

Waarom is dit boek dan toch van waarde? Omdat het inderdaad wel degelijk doet wat Zukin beoogt: aanzetten tot denken en een heroverweging van de eigen keuzes, wensen en voorkeuren. De uit het dagelijks leven geplukte voorbeelden zijn weliswaar allemaal gesitueerd in New York, maar grotendeels verplaatsbaar naar de West-Europese stedelijke omgeving. Kleine ondernemers verdwijnen overal ter wereld in 'opkomende' wijken, ten koste van yoghurtbars, koffietentjes, of hippe designerwinkels, vaak met lokale subsidie opgezet om de wijk een duwtje te geven. En inderdaad is het niet altijd fijn om na te denken wat er met de oorspronkelijke ondernemers en bewoners gebeurt als een wijk gentrificeert. Zet het boek dan ook echt aan tot actie? Dat wellicht niet altijd, maar het aan het licht brengen van deze 'ongemakkelijke waarheid' is al een goede eerste stap.

\section{Strijd om ruimte}

Zukin zegt niet geïnteresseerd te zijn om nog meer te schrijven over 'rechtvaardige steden', een discours dat volgens haar maar een bepaalde groep mensen aanspreekt en zeker niet de meerderheid van de bevolking die zij aan wil spreken. Toch gaat het boek wel degelijk over 'rechtvaardigheid'. Sterker nog, volgens Zukin gaat alle urbane wetenschap over democratie en gelijkheid. "Veel vrienden en collega's noemen deze periode een van liberalisme en revanchisme. Ik denk dat revanchisme een te sterke term is, maar feit is dat we zien dat de stedelijke centra weer eigendom worden van de rijke mensen, niet de armere mensen. Het is een situatie met meerdere kanten, maar wel een situatie waar rijkere mensen meer baat bij hebben dan armere."

De queeste naar authenticiteit en een authentieke stad komen uiteindelijk neer op de vraag wat een rechtvaardige stad is en wie er het recht op een (plek in) de stad heeft. Dit is een constant gevecht, tussen verschillende (groepen) gebruikers, ontwikkelaars en diverse andere actoren. Het recht op een stad is volgens haar het recht om op een plek te zijn, zo lang je geen wetten overtreedt en niet de behoeften van een ander schendt - een dunne scheidslijn, want behoeftes verschillen van elkaar en bijten elkaar. Ze neemt Union Square als voorbeeld: een voorheen rommelig en onveilig plein, dat opgeknapt is sinds het onderdeel is van een BID (Business Improvement District).

"Ik voel de paradox als ik er loop, want dan vind ik dat er teveel verkopers zijn, overal, ze drukken het publiek weg, nemen de plek over van mij als consument. Wat voor de ene teveel en te druk is, is voor de ander levendig. Het is een constante strijd om democratische manieren te vinden om het gebruik van openbare ruimte te verdelen. De stad is een arena van strijd - tussen producenten en consumenten van openbare ruimte - om onze behoeften met elkaar in balans te brengen."

\section{Jane Jacobs}

Naked City is ook een expliciete kritiek op (de uitwerking van) het gedachtegoed van Jane Jacobs, een andere auteur die het is gelukt 


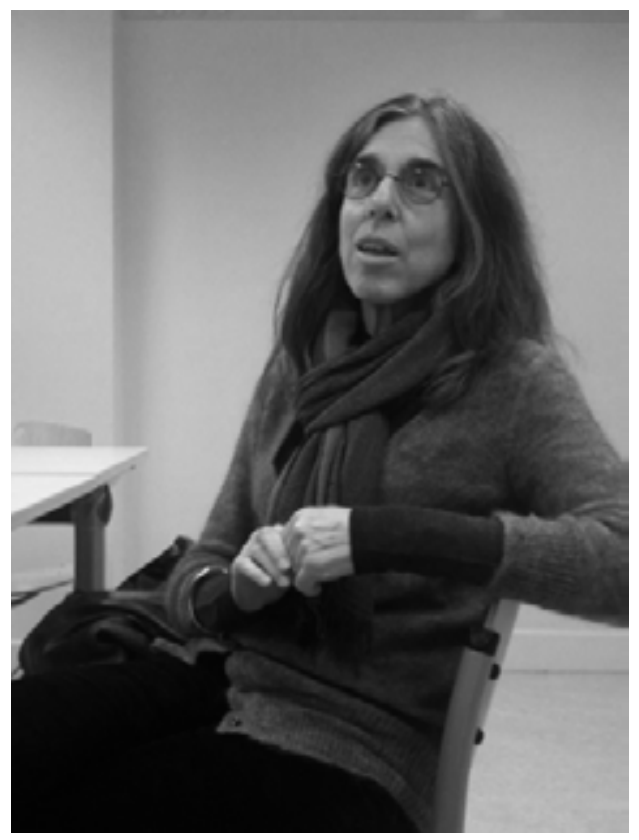

Sharon Zukin in gesprek met AGORA

aan te zetten tot actie. Jane Jacobs, activiste en publiciste heeft zowel in de wetenschap en de praktijk een stroming (New Urbanism) op gang gebracht en is in de hedendaagse planologie nog steeds invloedrijk. Zeker in New York, haar bakermat en ook het domein van het boek van Zukin. Zo steunt de City Planning Commission van New York in de geest van Jacobs veranderingen in zonering beleid (een van de belangrijkste planologische instrumenten in New York) waardoor de kleine schaal van vele straten worden behouden. Tegelijkertijd steunt de commissie de verlangens van de burgemeester om groei te bevorderen in de stad door de zonering van de grote straten te verruimen. Hier worden dan hoge nieuwe gebouwen mogelijk, terwijl de kleinschaligheid van de zijstraten behouden blijft. Dit verhoogt de vastgoedwaarde op twee manieren. Enerzijds door behoud van de laagbouw in de zijstraten voor de gentrifiers die oude huizen willen kopen, anderzijds doordat ontwikkelaars nieuwe hoogbouw in grote straten kunnen bouwen. Zukin merkt op dat er zo 'virtuele authenticiteit' wordt gecreëerd; men kan genieten van de mooie zijstraten met hun laagbouw. Echter, dit beleid van behoud van het oude en elders ruimte scheppen voor het nieuwe, is puur gericht op gebouwen. Het houdt geen rekening met wat er in de gebouwen gebeurt, wie er wonen, wie de gebruikers zijn. Jacobs hangt volgens Zukin een romantisch ideaal van New York en het New Yorkse leven aan, dat ontzettend tijdsgebonden is. Omdat Jacobs haar eigen buurt en beleving in de jaren '50 beschreef, was Jacobs zich niet bewust van haar beperkte, tijd- en plaatsgebonden referentiekader. De mensen, bewoners, winkeliers, gebruikers, om haar heen waren zo vanzelfsprekend, dat ze haar aandacht vooral richtte op de bebouwde omgeving en de veranderingen daarin. De authenticiteit die ook Jacobs zo pakkend beschrijft, hangt niet alleen af van de bebouwde omgeving, maar ook - en misschien wel vooral - van een economische en sociaal diverse bevolking en houdt alle dingen in, die vernietigd worden als de prijs van het vastgoed stijgt. Ook Jacobs haar volgelingen - onder wie vele beleidsmakers - hebben volgens Zukin deze blinde vlek voor de mensen die de authen- tieke sfeer bepalen, en zijn veel teveel gericht op virtuele authenticiteit.

\section{Hypes}

Zukin speelt met haar boek in op de overtuigingskracht van ruimtelijke hypes op het beleid, zowel in de keuze van het onderwerp en het daaraan verwante taalgebruik. Wetenschap en wetenschappelijke concepten zijn voor haar blijkbaar niet sexy genoeg om haar boodschap over te brengen. Daarom wendt ze zich tot de populaire cultuur om de mensen op straat te bereiken. Wat ze wil (en ook impliciet toegeeft) is zelf een hype tot verandering creëren, door het meeliften op dit hedendaagse taalgebruik en deze hedendaagse wensen en concepten. Met het vocabulaire van de straat, speelt Zukin in op trends in de samenleving. Niet de creatieve klasse, of rechtvaardige steden, maar authenticiteit moet de aandacht krijgen van burgers en beleidsmakers, net als 'walkability' die aandacht kreeg na Jacobs' interventie. Haar doel en middel om dit te bereiken zijn zeker te waarderen, het is alleen de vraag of het de taak van wetenschappers is om zich hiervoor te lenen, omdat het in dit geval ten koste van het wetenschappelijk gehalte van het boek gaat. . Wat zegt dit over haar wetenschapsopvatting? En is er iets voor te zeggen om het wetenschappelijk gehalte van een boek op te offeren ten behoeve van het bereiken van een groter publiek? Is het niet cynisch om ervan uit te gaan dat wetenschap niet het bereik heeft om echt iets voor elkaar te krijgen in de wereld? En is Richard Florida niet het bewijs dat je met populair wetenschappelijke taal en concepten een heel eind kan komen in de wereld en ook echt verandering teweeg kan brengen? Zelf merkt Zukin hierover op dat veel beleidsmakers verblind zijn door zijn 'retoriek' over de creatieve klasse. Eigenlijk eenzelfde verwijt dat ze maakt over de retoriek van Jacobs. Maar waarin verschilt haar eigen retoriek over authenticiteit dan?

Sharon Zukin lijkt op een hype mee te liften. Het begint een trend onder wetenschappers te worden om zich meer op de markt te richten, de wetenschap te laten voor wat het is en ten koste van wetenschappelijke precisie zich op een ander, breder publiek te richten. Buigen wetenschappers voor hippe termen, voor de taal van het volk, en gooien ze de wetenschap in de uitverkoop? Als dat inderdaad een hype is, is het er een die Zukin goed heeft begrepen; ze omhelst de espressocultuur en laat het rechtvaardigheidsjargon in de universiteit achter. Voor Zukin heiligt het doel de middelen. Als de wetenschap 'sexy' en vluchtiger moet op opdat er een groter publiek wordt bereikt, dan moet dat maar.

\section{Yvonne Rijpers (ymrijpers@gmail.com) is zelfstandig adviseur stedelijke ontwikkeling en coördinator bij de Vereniging Delta- metropool. Ze is tevens redacteur van AGORA.}

Literatuurselectie

Jacobs, J. (1961), The death and life of great American cities. New York: Random house.

Zukin, S. (2010), Naked city: the death and life of authentic urban places. Oxford: Oxford University Press. 